Politik Ekonomik Kuram 2020, Cilt 4(1), 20-44

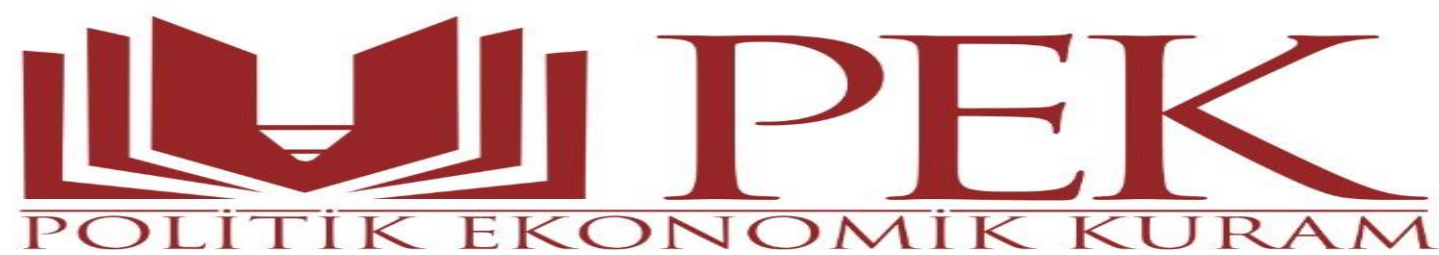

\title{
Türkiye'de Tütün Kontrol Politikaları ve Tütün Tüketimi Üzerine Bir Değerlendirme ${ }^{1}$
}

Sitkıcan SARAÇOĞLU², Fahriye ÖZTÜRK ${ }^{3}$

\section{Makale Bilgileri}

Makale Geçmişi:

Makalenin Yüklendiği Tarih: 30.04.2020

Makalenin Kabul Edildiği Tarih: 28.05.2020

Anahtar Kelimeler: Türkiye, Tütün tüketimi, Tütün kontrolü, Tütün Kontrol Çerçeve Sözleşmesi (TKÇS), MPOWER, Küresel Yetişkin Tütün Araştırması (KYTA), Küresel Gençlik Tütün Araştırması (KGTA).

https://doi.org/10.30586/pek.730271

\footnotetext{
${ }^{1} \mathrm{Bu}$ çalışma birinci yazarın ikinci yazar danışmanlığında hazırlamış olduğu doktora tezinden türetilmiştir.

${ }^{2}$ Arş. Gör. Ankara Hacı Bayram Veli Üniversitesi, İIBF, İktisat Bölümü, sitkican.saracoglu@ @bv.edu.tr

${ }^{3}$ Prof. Dr. Ankara Hacı Bayram Veli Üniversitesi, İ̈BF, İktisat Bölümü, fahriye.ozturk@ @bv.edu.tr
} 
Saraçoğlu S., Öztürk F. (2020), “Türkiye'de Tütün Kontrol Politikaları ve Tütün Tüketimi Üzerine Bir Değerlendirme”, Politik Ekonomik Kuram, Cilt 4(1)

\title{
Öz
}

Tütün tüketiminin sağllk ve ekonomi üzerinde yarattı̆̆l olumsuz etkileri bertaraf etmek amacıyla uygulanan tütün kontrol politikalarına dünya genelinde verilen önem, Dünya Bankası (DB) ve Dünya Sağllk Örgütü (DSÖ) liderliğinde yürütülen çalışmalar sayesinde 1990’lı yıllardan itibaren artmıştır. Bu artışta, “Tütün Kontrol Çerçeve Sözleşmesi (TKÇS)” ve “MPOWER” politika paketi önemli rol oynamıştır. Türkiye'de, 1996 yılında 4207 Sayılı Kanun'un ve 2004 yılında TKÇS'nin yürürlüğe girmesi, tütün kontrol politikalarındaki artışı beraberinde getirmiştir. Bu bağlamda bu çalışmanın amacı, Türkiye'de tütün kontrol politikalarının tarihsel gelişimi ve tütün tüketimine ilişkin bir değerlendirme yapmaktır.

\section{An Evaluation on Tobacco Control Policies and Tobacco Consumption in Turkey}

\begin{abstract}
The importance given to tobacco control policies implemented in order to eliminate the negative effects of tobacco consumption on health and economy has increased since the 1990s thanks to the studies conducted under the leadership of World Bank (WB) and World Health Organization (WHO). "Tobacco Control Framework Agreement (TCFA)" and “MPOWER" policy package played an important role in this increase. In Turkey, the implementation of Law No. 4207 in 1996 and the implementation of FCTC in 2004 have incremented the tobacco control policies. Accordingly, the aim of this study is to make an assessment of both the historical development of tobacco control policies and tobacco consumption in Turkey.
\end{abstract}

Keywords: Turkey, Tobacco Consumption, Tobacco Control, Framework Convention of Tobacco Control (FCTC), MPOWER, Global Adult Tobacco Survey (GATS), Global Youth Tobacco Survey (GYTS).

Jel Codes: D00, I12, 118 


\section{Giriş}

Tütün, 1950 öncesine kadar üretiminin yarattığı firsatlar nedeniyle önemli bir mal konumundayken, söz konusu tarihten sonraki çalışmaların bulgularının tütün tüketiminin ve tütün tüketiminden pasif etkilenimin bireylerin sağlığı üzerinde olumsuz etkilere yol açtığını ortaya koyması tütün kontrol politikası kavramını beraberinde getirmiştir. Tütün tüketiminin sağlık üzerindeki olumsuz etkilerinin yanı sıra ücret kaybına, azalan verimliliğe ve sağlık harcamalarında artışa yol açması tütün kontrol politikalarının uygulanmasını zorunlu kılmaktadır. Devletlerin tütün tüketimine müdahalesi, bir başka deyişle tütün kontrolü, bireylerin tütün tüketimine başlamalarını önleme, tütün tüketen bireylerin bırakmalarını sağlama ve bireylerin tütün tüketiminden pasif etkileniminin önlenmesine yönelik çok aşamalı bir müdahale sürecini işaret etmektedir.

Dünya genelinde tütün kontrolü konusunda, 1990'ların ilk yıllarında tütün üretimini destekleyici tavrından vazgeçerek tütün kontrolünün gerekliliğini işaret eden Dünya Bankası (DB) ve 1995 yılında tütün kontrolü konusunda uluslararası bir çerçeve geliştirmeyi hedefleyen kararlar alan Dünya Sağlık Örgütü (DSÖ) itici güç haline gelmiştir. DSÖ, tarafından 2000'li yıllarda önce "Tütün Kontrolü Çerçeve Sözleşmesi (Framework Convention of Tobacco Control, TKÇS) '” kabul edilmiş, sonrasında ise TKÇS'ye taraf ülkelere tütün kontrolü açısından rehber niteliğindeki MPOWER politika paketi açıklanmıştır.

Türkiye'de ise 24 Ocak 1980 Kararları sonrasında uluslararası tütün şirketlerinin iç piyasaya girmesiyle artan reklam faaliyetleri, sigara tüketiminde hızlı bir artışa yol açmıştır. Tütün kontrolüne ilişkin politikaların sınırlı olduğu Türkiye'de sigara tüketiminde 1980'li yıllarda yaşanan bu hızlı artış, tütün kontrolüne yönelik girişimlerin artmasına yol açmıştır. Devam eden süreçte, 1996 yılında 4207 Sayılı Kanun'un ve 2004 yılında TKÇS’nin yürürlüğe girmesi, tütün kontrolüne ilişkin uygulamaların artmasına neden olmuştur.

Türkiye'de tütün kontrol politikalarının tarihsel gelişimi ve tütün tüketimi üzerine bir değerlendirme yapmayı amaçlayan bu çalışmanın ikinci bölümünde dünyada tütün kontrol politikalarının tarihsel gelişimi ve üçüncü bölümünde ise Türkiye'de tütün kontrol politikalarının tarihsel gelişimi ele alınmaktadır. Çalışmanın dördüncü bölümünde Türkiye'de tütün tüketimini, Küresel Yetişkin Tütün Araştırması (KYTA), Küresel Gençlik Tütün Araştırması (KGTA) bulguları yardımıyla incelenmekte; çalışmanın sonuç bölümünde ise genel bir değerlendirme yer almaktadır. 
Saraçoğlu S., Öztürk F. (2020), “Türkiye'de Tütün Kontrol Politikaları ve Tütün Tüketimi Üzerine Bir Değerlendirme”, Politik Ekonomik Kuram, Cilt 4(1)

\section{Dünyada Tütün Kontrol Politikalarının Tarihsel Gelişimi}

Tütün üretiminin ülkeler açısından önemli iktisadi kazanımlar yarattığına dair hakim kanı, Wynder ve Graham (1950)'ın Amerika Birleşik Devletleri (ABD)'ni ve Doll ve Hill (1950)'in Birleşik Krallığı ele alan ve tütün tüketiminin bireylerin sağlığı üzerinde olumsuz etkilere yol açtığını ortaya koyan çalışmalarıyla sarsılmaya başlamıştır. Tütün endüstrisinin söz konusu ilişkiyi reddetme çabalarına rağmen, 1962 yılı “Birleşik Krallık Kraliyet Koleji Raporu (Royal College Report)” ve 1964 yılı “ABD Sağlık Bakanlı̆̆ı Danışman Kurulu Raporu (Surgeon General's Report)" sigara tüketimi ile akciğer kanseri arasındaki nedensellik ilişkisini ortaya koymuştur. 1964 yılına ait bu raporun tütün kontrolünün gerekliliğini işaret etmesi sonrasında $\mathrm{ABD}$, sağlık uyarılarının sigara paketleri üzerinde yer almasına ve sigara tüketiminin olumsuz etkileri hakkında halkın bilgilendirilmesine ilişkin uygulamaları yürürlüğe koymuştur. Benzer tütün kontrol politikaları Finlandiya, Norveç ve Singapur'un da aralarında olduğu birçok ülke tarafindan hızlı bir şekilde uygulanmaya başlamıştır (Wipfli ve Samet, 2016: 152-153).

1980'li yılların sonunda tütün tüketiminden pasif etkilenimin ölüm ve hastalıklara neden olduğuna dair bulguların elde edilmesiyle birlikte, tütün kontrol politikalarında önemli bir değişim yaşanmıştır. 1986 yılında ABD Sağlık Bakanlığ Ajansı ve ABD Ulusal Bilimler Akademisi'nin tütün tüketiminden pasif etkilenimin akciğer kanserine yol açtığına ilişkin bulguları ortaya koyması, sigara tüketmeyen bireylerin korunmasına yönelik tütün kontrol politikalarının uygulanmaya başlamasını beraberinde getirmiştir (Wipfli ve Samet, 2016: 153).

Bu gelişmelere rağmen, 1990'lı yılların başlarına kadar tütün üretimini destekleyen Dünya Bankası (DB), "tütün projelerinin küresel refah maliyetinin üretici ülkelere sağlanan kazancı büyük ölçüde aştı̆̆l” gerekçesi ve tütün tüketiminin sağlik üzerindeki olumsuz etkileri nedeniyle bu desteğini 1991 yılında kesmiş ve DB ekonomisti Barnum (1994)'un çalışması paradigma değişikliğini belirgin bir biçimde ortaya koymuştur. Barnum (1994)'a göre, sigara tüketen bireylerin büyük bir kısmının tütünün sağlık üzerindeki olumsuz etkileri hakkında eksik bilgiye sahip olması ve tütününün bağımlılık yaratıcı bir mal olması nedeniyle piyasa mekanizması koşulları işleyemeyecek ve tütün tüketiminin azaltılmasına yönelik bir devlet müdahalesi toplumsal refahı artıracaktır. DB tarafından bu yeni yaklaşım doğrultusunda yürütülen çalışmalar sonrasında, 1999 yılında hükümetlere "tütün kontrolüne yönelik çabalarını artırmalarını", "tütün kontrolü ile ilgili iktisadi konularda küresel düzeyde bilgi să̆lamalarını" ve "DSÖ ve paydaşlar ile yakın çalışmalarını” öneren “Curbing the Epidemic: Tobacco Control and Policies in Developing Countries" isimli rapor yayımlanmıştır (Mamudu 
Saraçoğlu S., Öztürk F. (2020), “Türkiye'de Tütün Kontrol Politikaları ve Tütün Tüketimi Üzerine Bir Değerlendirme”, Politik Ekonomik Kuram, Cilt 4(1)

vd., 2008: 3-4). Dünya Sağlık Örgütü (DSÖ) kanadında ise Dünya Sağlık Asemblesi, 1995 yılında tütün kontrolüne ilişkin uluslararası bir çerçeve geliştirmek yönünde bir karar almış ve bu yöndeki çalışmalar 1998 yılında Dünya Sağlık Örgütü Genel Direktörlüğüne Brundtland'ın seçilmesiyle birlikte ivme kazanmıştır (Mukaigawara vd., 2018: 6). DSÖ tarafından yürütülen söz konusu çalışmaların daha kapsayıcı bir biçime dönüşmesini sağlayan gelişme ise "mevcut ve gelecek nesillerin tütün tüketiminden ve tütün dumanına maruz kalmaktan korunması", amacını taşıyan "Tütün Kontrolü Çerçeve Sözleşmesi (Framework Convention of Tobacco Control, TKÇS) ”nin 2003 yılında DSÖ’nün 56. Dünya Sağlık Asamblesi'nde kabul edilmesiyle birlikte yaşanmıştır (Aslan, 2010: 124). TKÇS, 11 Bölümden oluşmasına rağmen TKÇS'nin temel politika önerileri 3.Bölüm (Tütün Talebini Azaltıcı Önlemler) ve 4. Bölüm (Tütün Arzını Azaltıcı Önlemler) içerisinde yer almaktadır. TKÇS'de yer alan tütün talebinin azaltılmasına yönelik önlemler Tablo 1'de yer almaktadır (Bilir, 2016: 8-9):

\section{Tablo 1: TKÇS'de yer alan tütün talebini azaltıcı önlemler}

\begin{tabular}{|c|c|}
\hline $\begin{array}{l}\text { Tütün talebini azaltıcı fiyat ve vergi önlemleri: Bilhassa } \\
\text { gençlerin sigara tüketimine başlamasını engellemek } \\
\text { amacıyla, taraf ülkeler ulusal politikalarıyla uyumlu fiyat ve } \\
\text { vergi politikaları uygulamalı, tütün ürünlerinde gümrüksüz ve } \\
\text { vergisiz satış yasaklanmalı ya da sınırlandırılmalıdır. }\end{array}$ & $\begin{array}{l}\text { Tütün talebinin azaltılmasında fiyat dıșı önlemler: Talebin } \\
\text { azaltılmasına ilişkin fiyat dışı konularla ilgili yasal } \\
\text { düzenlemeler yapılmalı ve uygulanmalıdır. }\end{array}$ \\
\hline $\begin{array}{l}\text { Tütün dumanından korunma: Toplu ulaşımda, kapalı iş } \\
\text { yerlerinde, kamusal alanlarda vb. alanlarda bireylerin tütün } \\
\text { tüketiminden pasif etkileniminin önlenmesine yönelik } \\
\text { önlemler alınmalıdır. }\end{array}$ & $\begin{array}{l}\text { Tütün ürünlerinin içerikleri: Taraf ülkeler, tütün ürünlerinin } \\
\text { içerikleri ve yaydıkları maddelerin ölçümüne ilişkin ilkeleri } \\
\text { belirleyerek ilgili idari ve yasal önlemleri almalıdır. }\end{array}$ \\
\hline $\begin{array}{l}\text { Tütün ürünlerinin ifșası: Üreticilerin ve ithalatçıların, tütün } \\
\text { ürünlerinin içerdikleri ve yaydıkları maddelere ilişkin } \\
\text { bilgileri yetkililere bildirmesi, bu konuyla ilgili gerekli } \\
\text { mekanizmaların oluşturulması ve tütün ürünlerinin zehirli } \\
\text { maddeler yaydığı konusunda kamuoyunun bilgilendirilmesi } \\
\text { gerekmektedir. }\end{array}$ & $\begin{array}{l}\text { Tütün ürünlerinin paketlenmesi ve etiketlenmesi: Paketler } \\
\text { üzerinde tütün ürünlerinin sağlı̆ga etkileri ve emisyonlarına } \\
\text { ilişkin yanıltıcı mesajların, bir ürünün nispeten daha az zararlı } \\
\text { olduğu algısını oluşturacak ibare, renk, işaret vb. kullanılması } \\
\text { yasaklanmaktadır. Ayrıca, paketlerde yetkililerin onayladığı } \\
\text { uyarı yazıları ve resimlerin yer alması zorunludur. }\end{array}$ \\
\hline $\begin{array}{l}\text { Eğitim, ögretim, iletișim ve toplumsal bilinç: Her türlü eğitim } \\
\text { aracının kullanılarak, tütün ürünleri tüketiminin olumsuz } \\
\text { etkilerine ilişkin eğitim ve bilgilendirme yapılmasının } \\
\text { gerekliliği vurgulanmaktadır. }\end{array}$ & $\begin{array}{l}\text { Tütün reklamı, promosyonu ve sponsorluğu: Taraf ülkeler, } \\
\text { tütün endüstrisinin reklam, promosyon vb. faaliyetlerini } \\
\text { kısıtlamalı veya yasaklamalı ve bu konuda uluslararası işbirliği } \\
\text { yapmalıdır. }\end{array}$ \\
\hline
\end{tabular}

Kaynak: Bilir (2016: 8-9).

TKÇS'de yer alan tütün arzının azaltılmasına yönelik önlemler Tablo 2'de yer almaktadır (Bilir, 2016: 9): 
Saraçoğlu S., Öztürk F. (2020), “Türkiye'de Tütün Kontrol Politikaları ve Tütün Tüketimi Üzerine Bir Değerlendirme”, Politik Ekonomik Kuram, Cilt 4(1)

\section{Tablo 2: TKÇS'de yer alan tütün arzının azaltıcı önlemler}

\begin{tabular}{|l|l|}
\hline \multicolumn{3}{|c|}{ Tütün Arzını Azaltıcı Önlemler } \\
\hline Tütün ürünlerinin yasa dıșı ticareti: Taraf ülkelerde tütün & Cocuklara ve çocuklar aracıllğıyla satıș yapılması: Taraf \\
\hline ürünü paketlerinde ürünlerin kaynağının net biçimde & ülkelerde, 18 yaş veya belirlenmiş yaş sınırının altındakilere \\
belirtilmesi, tütün ürünleri dolaşımının kontrolü ile kaçak ve & tütün ürünleri satışını önleyecek önlemler alınmalı, çocukların \\
sahte sigaraların ticaretinin engellenmesine yönelik idari ve & kolaylıkla ulaşabileceği konumda ve daha elverişli olan küçük \\
yasal önlemlerin alınması gerekliliği vurgulanmıştır. & paketler halinde satışa sunulmamalı, ücretsiz olarak \\
dağıtılmamalı ve otomatik satıs makineleri ile satılmamalıdır.
\end{tabular}

Kaynak: Bilir (2016: 9).

2008 yılında DSÖ, TKÇS'ne taraf ülkelere tütün kontrolü sürecinde yardım etmek amacıyla, tütün kontrol politikalarını pratiğe dönüştürmeleri, gerekli finansal kaynaklara erişimin sağlanması ile ulusal ve uluslararası düzeydeki işbirliğinin sağlanması konularını ele alan ve tütünsüz yaşamı destekleyici yasal ve sosyoekonomik unsurları ön planda tutan MPOWER politika paketini açıklamıştır (Ergüder, 2010: 83-85). MPOWER paketinde taraf ülkelere önerilen tütün kontrol politikası stratejileri Tablo 3'de yer almaktadır (Ergüder, 2010: 87):

\section{Tablo 3: MPOWER paketinin politikaları ve müdahaleleri}

\begin{tabular}{|c|c|}
\hline $\begin{array}{lr}\text { M } & (\text { MONITOR, } \\
\text { İLEE): } & \text { Tütün } \\
\text { tüketiminin izlenmesi }\end{array}$ & $\begin{array}{l}\text { P (PROTECT, KORU): Bireylerin tütün tüketiminden pasif etkileniminin önlenmesi. } \\
\text { Müdahale-1: Eğitim ve sağlık kuruluşları, işyerleri vb. kapalı alanlarda dumansız bir çevre için } \\
\text { yasal düzenlemelerin oluşturulması ve uygulanması. }\end{array}$ \\
\hline \multirow{4}{*}{$\begin{array}{lr}\text { Kesişen } & \text { aktivite: } \\
\text { Yetişkin ve gençlerde } \\
\text { tütün tüketiminin } \\
\text { temel göstergelerini } \\
\text { veren, } \\
\text { özellikleri yansitan, } \\
\text { nüfus bazlı periyodik } \\
\text { verilerin } \\
\text { edilmesi }\end{array}$} & $\begin{array}{l}\text { O (OFFER, ÖNER) : Bireylere tütün tüketiminin bırakılmasının önerilmesi. Müdahale-1: Sağlık } \\
\text { sisteminin tütün tüketiminin bırakılmasını önerecek biçimde kuvvetlendirilmesi, bırakma hattı vb. } \\
\text { girişimlerin desteklenmesi ve düşük maliyetli ilaç tedavilerine erişimin kolaylaştırılması. }\end{array}$ \\
\hline & $\begin{array}{l}\text { Müdahale-1: Paketlerde etkili uyarı etiketlerinin oluşturulması. } \\
\text { Müdahale-2: Tütün karşıtı reklamların uygulanması. } \\
\text { Müdahale-3: Tütün karşıtı faaliyetlerde medyanın kullanılması. }\end{array}$ \\
\hline & $\begin{array}{l}\text { E (ENFORCE, YASAKLA): Tütün reklam, promosyon vb. faaliyetlerin yasaklanması. } \\
\text { Müdahale-1: Tütüne ilişkin doğrudan reklam, promosyon ve sponsorluğun yapılmasını engelleyen } \\
\text { gerekli düzenlemelerin yapılması ve uygulanması. } \\
\text { Müdahale-2: Tütüne ilişkin tüm reklam, promosyon ve sponsorluğun yapılmasını engelleyen } \\
\text { gerekli yasal düzenlemelerin yapılması ve uygulanması. }\end{array}$ \\
\hline & $\begin{array}{l}\text { R (RAISE, VERGILENDİR): Tütün ürünlerindeki vergi oranlarının artırılması. } \\
\text { Müdahale-1: Tütün ürünlerindeki vergilerin enflasyonla uyumlu hale getirilmesi, vergi } \\
\text { oranlarındaki artışın tüketicilerin alım gücünden daha yüksek oranda gerçekleştirilmesi. } \\
\text { Müdahale-2: Tütün ürünlerine ilişkin yasadışı ticaretin azaltılması amacıyla vergi ile ilgili } \\
\text { düzenlemelerin güçlendirilmesi. }\end{array}$ \\
\hline
\end{tabular}

Kaynak: Ergüder (2010: 87). 
Buraya kadar belirtilen tüm gelişmeler, Dünya Bankası ve DSÖ önderliğinde gösterilen çabalar sayesinde tütün kontrol politikalarına verilen önemin dünya genelinde özellikle 1990'l1 yıllardan itibaren arttığını işaret etmektedir. Tütün kontrol politikalarının dünya genelinde tarihsel gelişimine yer verildikten sonra, söz konusu politikaların Türkiye üzerindeki yansımalarından söz etmek yerinde olacaktır.

\section{Türkiye'de Tütün Kontrol Politikalarının Tarihsel Gelişimi}

Türkiye'de 1980'li yıllar öncesinde tütün üretimi, sigara üretimi, tütün ürünlerinin fiyatlandırılması ve satışı, Türkiye Cumhuriyeti'nin ilk kurumları arasında yer alan ve devlet tekeli niteliği taşıyan “TEKEL”in kontrolü altındaydı (Bilir ve Özcebe, 2011: 60). 24 Ocak 1980 Kararları, Türkiye tütün sektörünün ticaretteki ve yatırımdaki serbestleştirmeler ve özelleştirme kanalıyla TEKEL'in denetiminden çıkarılarak uluslararası tütün şirketlerinin belirleyiciliğine açılmasına neden olmuştur. Söz konusu şirketlerin Türkiye piyasasına girmesiyle birlikte reklam, promosyon vb. faaliyetlerin artması da sigara tüketimindeki hızlı artışı beraberinde getirmiştir (Gültekin Karakaş ve Yı1maz, 2014: 19).

1980 öncesinde tütün kontrolü politikası olarak yalnızca sigara reklamlarının televizyon, radyo ve panolarda yasaklandığg Türkiye'de sigara tüketiminde 1980'li yıllarda yaşanan bu hızlı artış, tütün kontrolüne yönelik girişimlerin de artmasını beraberinde getirmiştir. Tütün kontrolüne ilişkin ilk kanun tasarısı 1991 yılında serbest ticareti aksatacağı gerekçesiyle; ikinci kanun tasarısı ise 1992 yılında tütünün sağlık üzerindeki olumsuz etkileri hakkında yeterli kanıt bulunmadığı gerekçesiyle uygulamaya konulamamıştır. 1993 yılında, tütün kontrolü ile ilgili ilk sempozyum gerçekleştirilmiş ve 1995 yılının Mayıs ayında, Sigara ile Mücadele ve Sağlığı Geliştirme Derneği, Türk Hekimler Birliği, Halk Sağlığı Kurumu, Halk Sağlığı Uzmanları Derneği ve Türk Toraks Derneği'nin önderliğinde Sigara ve Sağlık Ulusal Komitesinin (SSUK) kurulmasına ilişkin faaliyetlere başlanmıştır. Söz konusu paydaşlar tarafından hazırlanan Ulusal Tütün Kontrol Programı, ileriki yıllarda ulusal kanunların oluşturulmasında, TKÇS'nin kabul edilmesinde ve uygulamaya geçirilmesinde önemli paya sahip olmuştur (Yürekli vd., 2010: 21; Bilir ve Özcebe, 2013: 98; Bilir vd., 2009: 69).

Türkiye'de tütün kontrolü açısından en önemli kilometre taşlarından biri, 26 Kasım 1996 tarihli ve 22829 sayılı Resmi Gazete'de yayınlanan “Tütün Mamullerinin Zararlarının Önlenmesine Dair 4207 Sayılı Kanun”dur (Kılınç ve Günay, 2014: 5). 4207 Sayılı Kanun ile birlikte tütün kontrolü açısından sağlanan önemli kazanımları aşağıdaki biçimde ifade etmek mümkündür (4207 Sayıl1 Kanun, 1996): 
- Kamu binalarının kapalı alanlarında tütün ürünleri tüketimi yasaklanmıştır.

- İkamete konu olan konutlar dışarıda tutulmak şartıyla sağlık, eğitim, spor, kültür, eğlence vb. amaçlı ve birden çok kişinin girebileceği özel kişilere ait yapıların kapalı alanlarında tütün ürünlerinin tüketimi yasaklanmıştır.

- Taksi, denizyolu, havayolu, karayolu ve demiryolu toplu ulaşım araçlarında tütün ürünlerinin tüketimi yasaklanmıştır.

- Okul öncesi, ilk ve orta düzeyde eğitim ve öğretim kurumları (özel kişilere ait olanlar da dahil olmak üzere) ile sosyal hizmet ve kültür binalarının kapalı ve açık alanlarında tütün ürünleri tüketimi yasaklanmıştır.

- Tütün ürünleri ve üretici firmaların marka, amblem vb. kullanarak reklam ve tanıtım yapmaları, söz konusu ürünlerin tüketimini özendirici kampanyaları düzenlemeleri ve etkinlikleri isimlerini, marka veya amblemlerini kullanarak desteklemeleri yasaklanmıştır.

- Tütün ürünlerinin paketlerine, bu ürünlerin zararlarını belirten uyarıların eklenmesi zorunluluğu getirilmiştir.

- Tütün ürünlerinin, 18 yaşını doldurmamış bireylerin kolayca ulaşabileceği ve işletme dışından görebileceği biçimde satışa sunulması yasaklanmıştır.

- TV kanalları ve radyolara, ayda en az 90 dakika olmak üzere tütün tüketiminin zararlarına ilişkin bilgilendirici yayın yapma zorunluluğu getirilmiştir.

Düzenleme açısından geniş kapsamlı olan 4207 Sayılı Kanun'un uygulanmasında yaptırımların eksikliği nedeniyle ortaya çıkan problemler, bu kanunun tütün tüketimini azaltıcı etkisinin sınırlı olmasına yol açmıştır (Yürekli vd., 2010:21). Diğer taraftan, 1994, Kasım 2000 ve Şubat 2001 'de yaşanan ekonomik krizler sonrasında yapısal reformları içeren “Güçlü Ekonomiye Geçiş Programı (GEGP)"nın uygulamaya konulmasıyla birlikte özelleştirme programının ivedilikle tamamlanması, özel sektörün üretimi gerçekleştirebileceği alanlardan (tütün piyasaları gibi) devletin çekilmesi ve bu ürünlerin serbest piyasa koşullarına bırakılması hedeflenmiştir (Şahin, 2011: 260). Bu hedefin gerçekleştirilmesini destekleyen ve Tütün, Tütün Mamulleri ve Alkollü İçkiler Piyasası Düzenleme Kurumunun (sonraki adı Tütün ve Alkol Piyasası Düzenleme Kurumu-TAPDK) kurulmasını, söz konusu kurumun yetki ve görevleri ile tütün ve tütün ürünlerinin Türkiye'de üretimi, iç ve dış alımı ve satımı ile ilgili ilkeleri düzenleyen “4733 Sayılı Kanun”, 9 Ocak 2002 tarihli ve 24635 sayılı Resmi Gazete'de yayımlanarak uygulamaya konulmuştur (4733 Sayılı Kanun, 2002). Söz konusu kanunun en belirgin niteliği, tütün sektöründe destekleme alımlarının kaldırılması, sektöre yazılı sözleşme esasının getirilmesi ve TEKEL'in yapısının değiştirilerek özelleştirme için hazır duruma getirilmesidir (Gümüş ve Güler Gümüş, 2005: 84-85). 
Bu arada TKÇS, Türkiye tarafından uygun bulunmuş ve 28 Nisan 2004 tarihinde imzalanarak 25 Kasım 2004 tarihinde yürürlüğe girmiştir (Bilir, 2016: 8). TKÇS doğrultusunda, "Ulusal Tütün Kontrolü Komitesi" kurulmuş ve "Ulusal Tütün Kontrolü Programı ve Eylem Planı" hazırlanmıştır. 2006 yılında Başbakanlık Genelgesi olarak yayınlanan ve 2008-2012 dönemini kapsayan "Ulusal Tütün Kontrolü Programı ve Eylem Planı" aşağıda yer alan 10 temel başlıktan oluşmaktadır (T. C. Sağlık Bakanlığı Tütün ve Diğer Bağımlılık Yapıcı Maddelerle Mücadele Daire Başkanlığı, 2014: 17):

- Tütün tüketiminin sağlık üzerinde yarattığı olumsuz etkiler hakkında toplumun bilgilendirilmesi ve bilinçlendirilmesi,

- Sigara tüketiminin bırakılmasının sağlanması,

- Fiyat ve vergilendirmenin artırılması,

- Bireylerin tütün tüketiminden pasif etkileniminin önlenmesi,

- Tütün ürünleri ile ilgili reklam, promosyon ve sponsorluğun yasaklanması,

- Tütün ürünlerinin kontrolü ve tüketicinin bilgilendirilmesi,

- Tütün ürünlerinin yasa dişı ticaretinin engellenmesi,

- Gençlerin tütün ürünlerine ulaşabilirliğinin engellenmesi,

- Tütün üretiminin azaltılması ve alternatif politikaların üretilmesi,

- Tütün tüketimi ve kontrol yöntemlerinin izlenmesi ve değerlendirilmesidir”.

Söz konusu başlıklar sonraki yıllarda hazırlanan, “2015-2018 Ulusal Tütün Kontrol Programı Eylem Planı” ve “2018-2023 Tütün Kontrolü Strateji Belgesi ve Eylem Planı”nda da yer almaktadir.

TKÇS'nin getirdiği yükümlülükler aynı zamanda, 4207 Sayılı Kanun'un TKÇS ile uyumlu hale getirilmesini gerekli kılmış ve yürütülen çalışmalar sonucunda (Kılınç ve Günay, 2014: 5) “5727 sayılı Tütün Mamullerinin Zararlarının Önlenmesine Dair Kanunda Değişiklik Yapılması Hakkında Kanun”, 19.01.2008 tarihli ve 26761 sayılı Resmi Gazete'de yayımlanarak uygulamaya konulmuştur (5727 Sayılı Kanun, 2008). 4207 Sayılı Kanun’un içeriğini genişleten ve kanunun adını "Tütün Ürünlerinin Zararlarının Önlenmesi ve Kontrolü Hakkında Kanun” biçiminde değiştiren 5727 Sayılı Kanun' da amaç, “kişileri ve gelecek nesilleri tütün ürünlerinin zararlarından, bunların alışkanlıklarını özendirici reklam, tanıtım ve teşvik kampanyalarından koruуиси tertip ve tedbirleri almak ve herkesin temiz hava soluyabilmesinin sağlanması yönünde düzenlemeler yapmak” biçiminde belirtilmiştir (5727 Sayılı Kanun, 2008).

Buradan hareketle, söz konusu kanun, 19 Mayıs 2008'den itibaren taksilerde, tüm halka açık binalarda, eğitim ve sağlık kuruluşları ile spor tesislerinin içerisinde ve dışarısında sigara tüketimini yasaklayarak, söz konusu alanları \%100 dumansız hava sahası ilan etmiştir. 19 
Saraçoğlu S., Öztürk F. (2020), “Türkiye'de Tütün Kontrol Politikaları ve Tütün Tüketimi Üzerine Bir Değerlendirme”, Politik Ekonomik Kuram, Cilt 4(1)

Temmuz 2009 tarihinden itibaren, sigara yasağı konaklama ve ikram sektöründe de uygulanmaya başlanmıştır. 5727 Sayılı Kanun ile birlikte, Türkiye Avrupa'da 5., Orta Doğu ve Orta Asya'da ise ilk dumansız hava sahasına sahip ülke olmuştur (Yürekli vd., 2010: 21). 5727 Sayılı Kanun'un 4207 Sayılı Kanun'dan ilk farkı, tüm kamusal kapalı alanların tütün tüketimi yasağının kapsamına alınmasıdır. İkinci fark ise 4207 Sayılı Kanun'da cezanın nasıl uygulanacağı net bir biçimde ifade edilmemiş iken 5727 Sayılı Kanun, cezanın uygulanmasını açık ve net bir biçimde belirtmektedir. 5727 Sayılı Kanun'un yürürlüğe girmesiyle birlikte Türkiye, TKÇS ile uyumlu bir kanuna sahip olmuştur (Bilir, 2016: 10).

Türkiye'de MPOWER kriterlerinin yerine getirilme durumuna bak1lacak olursa, M harfinin işaret ettiği “monitor”, bir başka deyişle "tütün kullanımını izle” politikası kapsamında DSÖ ve ABD Hastalıkları Önleme ve Kontrol Merkezi (CDC)'nin ortak girişimi olan KTSS (Küresel Tütün Sürveyans Sistemi, GTSS), Türkiye üzerinde çalışmalara başlamıştır. Bu bağlamda Türkiye'de gençlere odaklanan, ulusal düzeyde temsiliyete sahip ve okul tabanlı bir araştırma olan KGTA (Küresel Gençlik Tütün Araştırması, GYTS); 2003, 2009, 2012 ve 2017 yıllarında ve 15 yaş ve üzeri yetişkinlerin tütün tüketimini izleyen ulusal düzeyde temsiliyete sahip bir hanehalkı araştırması olan KYTA (Küresel Yetişkin Tütün Araştırması, GATS) ise 2008, 2012 ve 2016 yıllarında gerçekleştirilmiştir (CDC, 2019a).

MPOWER paketinde P harfi ile ifade edilen "protect", bir başka deyişle "bireylerin pasif sigara etkileniminden korunması" politikası kapsamında, tütün kullanımından pasif etkilenen bireylerin ve tüm toplumun temiz hava hakkını korumayı amaçlayan 5727 Sayılı Kanun'un etkili bir biçimde uygulanmasını sağlamak amacıyla güçlü bir denetim mekanizması geliştirilmiştir. Bu doğrultuda, ilgili kanunun ihlallerine ilişkin şikayetlerin, "Yeşil Dedektör" mobil uygulaması veya “ALO 184 Sağlık Bakanlı̆̆l İletişim Merkezi (SABİM)” kanalıyla Sağlık Bakanlığı (SB)'na aktarıldığı “Dumansız Hava Sahası Denetim Sistemi (DHSDS)"ne geçilmiştir. GPS destekli denetimlerin gerçekleştirildiği söz konusu sistem, 30 Eylül 2012 tarihinden itibaren 81 ili kapsar hale gelmiştir (T. C. Sağlık Bakanlığı Tütün ve Madde Bağımlılığı ile Mücadele Dairesi Başkanlığı, 2019).

MPOWER paketindeki O harfinin işaret ettiği "offer", bir başka deyişle "bireylere tütün tüketiminin bırakılması için yardım teklif edilmesi” politikası kapsamında, Türkiye'de sigarayı bırakma davranışı özendirilirken "ALO 171 Sigara Bırakma Danışma Hattı” ve sigara bırakma poliklinikleri kanalıyla hizmet verilmektedir. “ALO 171 Sigara Bırakma Danışma Hattı”nda bireyler sigaranın zararları hakkında bilgilendirilmekte ve bağımlılık düzeyleri belirlenmeye çalışılmaktadır. 23.11.2011 tarihli ve 28121 sayılı Resmi Gazete'de yayımlanarak uygulamaya 
Saraçoğlu S., Öztürk F. (2020), “Türkiye'de Tütün Kontrol Politikaları ve Tütün Tüketimi Üzerine Bir Değerlendirme”, Politik Ekonomik Kuram, Cilt 4(1)

konulan “Tütün Bağımlılığı Tedavi ve Eğitim Birimleri Hakkındaki Yönetmelik” doğrultusunda yürütülen sigara bırakma polikliniği hizmetleri ise 2009 yılında 62 poliklinik tarafından sunulurken, 2019 yılı itibariyle hizmet sunan poliklinik sayısı 532'ye ulaşmıştır (T. C. Sağlık Bakanlığı Tütün ve Madde Bağımlılığı ile Mücadele Dairesi Başkanlı̆̆ı, 2019).

MPOWER paketinde yer alan W harfinin işaret ettiği "warn”, bir başka deyişle, "bireylerin tütünün zararları ile ilgili uyarılması” kriteri ele alındığında 5727 Sayılı Kanun'da; TV kanalları ve radyolarına getirilen tütün tüketiminin zararları konusunda bilgilendirici yayın yapma zorunluluğunun, en az 30 dakikasının 17:00-22:00 aralığında olmak koşuluyla 08:00-22:00 aralığında ve ayda en az 90 dakika olarak gerçekleştirileceği belirtilmiştir. Ayrıca aynı kanun, tütün ürünü paketlerinde en geniş iki yüzden, bir yüzüne toplam alanın \%40'ından, diğer yüzüne ise \%30'undan az olmayacak biçimde tütün ürünlerinin zararlarını içeren Türkçe yazılı uyarı ya da mesajların bulundurulması yükümlülüğünü getirmiştir. Ayrıca, tütün ürünü paketlerinde ve etiketlerinde aldatıcı tanımlama, marka, renk veya işaret kullanılamayacağı ve bu ürünlere ilişkin eksik ve yanlış bilgi verilemeyeceği hükme bağlanmıştır (5727 Sayılı Kanun, 2008). “Tütün Mamullerinin Zararlarından Korumaya Yönelik Üretim Şekline, Etiketlenmesine Ve Denetlenmesine İlişkin Usul ve Esaslar Hakkında Yönetmelik” üzerinde 27.02.2010 tarihli ve 27506 sayılı Resmî Gazetede yayımlanarak uygulamaya konulan değişiklikle birlikte tütün ürünü paketlerinde birleşik uyarılar (resimli ve yazılı sağlık uyarıları) kullanılmaya başlanmış ve genel uyarının tütün ürünü paketinin geniş dış yüzünün yüzde \%30'unu ve birleşik uyarının ise diğer geniş dış yüzün \%65'ini kaplaması gerekliliği belirtilmiştir (27506 sayılı Resmî Gazete, 2010). Bunun yanı sıra, "Sağlık Bakanlığı ve Bağlı Kuruluşlarının Teşkilat ve Görevleri Hakkında Kanun Hükmünde Kararname ile Bazı Kanun ve Kanun Hükmünde Kararnamelerde Değişiklik Yapılmasına Dair Kanun”un 12.07.2012 tarihli ve 28351 sayılı Resmi Gazete'de yayımlanarak uygulamaya konulmasıyla birlikte, tütün ürünü paketlerinde, alanlarının \%65'inden az olmaması koşuluyla resimli ve yazılı uyarıların bulundurulması yükümlülüğü getirilmiş (6354 Sayılı Kanun, 2012) ve "Sağlıkla İlgili Bazı Kanun ve Kanun Hükmünde Kararnamelerde Değişiklik Yapılmasına Dair Kanun”un 05.12.2018 tarihli ve 30616 sayılı Resmi Gazetede yayımlanarak uygulamaya konulmasıyla birlikte uyarı alanının boyutu, \%65'ten \%85'e çıkarılmıştır (7151 Sayılı Kanun, 2018).

MPOWER paketinin E harfinin gösterdiği "enforce", bir başka deyişle, "tütün reklam, promosyon ve sponsorluk yasaklarının uygulanması" politikası söz konusu olduğunda, 5727 Sayılı Kanunun uygulamaya konulması sonrasında, tütün ürünlerine ilişkin sponsorluk yasağı getirilmiştir. Ayrıca kanun, tütün ürünlerinin işletmelerin dışarısından görülebilecek biçimde 
satışa sunulmasını yasaklamış ve tütün ürünlerine tüketicilerin doğrudan değil ancak yetkili bir kişi aracılığıyla ulaşabileceğini belirtmiş̧tir. Bunlara ilaveten, 2011 yılı Temmuz ayındaki düzenlemeyle birlikte tütün ürünlerinin kapalı dolaplar içerisinde satışa sunulması zorunluluğu getirilmiştir (T. C. Sağlık Bakanlığı Tütün ve Diğer Bağımlılık Yapıcı Maddelerle Mücadele Daire Başkanlığı, 2014: 19). Ayrıca, TV programlarında, sinemada, tiyatroda, internet, sosyal medya vb. ortamlarda tütün ürünlerine ilişkin görüntülere yer verilemeyeceği ve sağlık, eğitim, spor vb. kuruluşlarda ve üniversite yerleşkelerinde tütün ürünlerinin satılamayacağı karara bağlanmıştır (7151 Sayılı Kanun, 2018). Bunların yanı sıra, tütün ürünlerinin, markalara ilişkin renk, yazı, şekil ve konum açısından tümüyle aynı biçimde tasarlandığı standart ve düz paketlerle satışa sunulmasına ilişkin düzenlemeleri içeren "Tütün Mamullerinin Üretim Şekline, Etiketlenmesine ve Denetlenmesine İlişkin Usul ve Esaslar Hakkında Yönetmelik” 01.03.2019 tarihli ve 30701 sayılı Resmi Gazetede yayımlanarak yürürlüğe girmiştir. Bu yönetmeliğin uygulamaya konulmasının ardından, düz paket uygulamasının gerekliliklerini taşımayan tütün ürünlerinin 05.12.2019 tarihi itibariyle piyasaya arzı ve 05.01.2020 tarihi itibariyle ise piyasada bulundurulması yasaklanmıştır (30701 Sayılı Resmî Gazete, 2019).

MPOWER paketinin R harfinin işaret ettiği "raise", bir başka deyişle "tütün ürünlerindeki vergi oranlarının artırılması" politikası çerçevesinde, DSÖ tütün ürünlerinde en az \%75 oranında vergi uygulanmasını önerirken, söz konusu oran Türkiye'de 2019 yılında \%82,25 olarak gerçekleşmiştir (T. C. Sağlık Bakanlığı Tütün ve Madde Bağımlılığı ile Mücadele Dairesi Başkanlığg1, 2019).

Tütün kontrolüne ilişkin söz konusu düzenlemelerin hayata geçirilmesi sonrasında Türkiye'nin; DSÖ’nün “2013 Küresel Tütün Epidemisi Raporu”nda M-POWER stratejilerinin tümünü uygulayan ilk ülke ve "2019 Küresel Tütün Epidemisi Raporu”nda ise Brezilya ile birlikte MPOWER politika paketi kriterlerinin tamamını yerine getiren iki ülkeden biri olduğu vurgulanmıştır (T. C. Sağlık Bakanlığı Tütün ve Madde Bağımlılığı ile Mücadele Dairesi Başkanlığ 1 , 2019).

\section{Türkiye'de Tütün Tüketimi}

1980'li yıllarda uluslararası tütün şirketlerinin Türkiye piyasasına girmesiyle birlikte reklam, ürün farklılaştırma vb. faaliyetlerin artması, tütün tüketiminde hızlı bir artışı beraberinde getirmiş ve sigara tüketimi 1960-2000 döneminde yıllık 30 milyar sigaradan 118 milyara yükselmiştir. Tütün tüketimindeki söz konusu artış, 1996 tarihli “Tütün Mamullerinin Zararlarının Önlenmesine Dair 4207 Sayılı Kanun” ve 2008 tarihli “5727 sayılı Tütün Ürünlerinin Zararlarının Önlenmesi ve Kontrolü Hakkında Kanun ”un getirdiği uygulamaların 
başlamasıyla önce durmuş, bir süre yatay olarak seyretmiş; 2009-2011 döneminde ise azalış trendine girmiştir. Diğer taraftan, Türkiye'de tütün tüketimi 2011-2013 döneminde iniş-çıkışlı bir seyir izlemiş; 2013 ve sonrasında ise keskin bir artış göstererek 2018 y1lında, 2000 yılındaki düzeyine ulaşmıştır. Diğer taraftan, 2013 ve sonrasında tütün tüketiminde görülen artış eğilimi, söz konusu dönemde tütün kontrolüne yönelik hayata geçirilen uygulamaların tütün kontrolünü etkin bir biçimde sağlayamadığını gözler önüne sermektedir. Söz konusu durum aşağıdaki Şekil 1 'de gösterilmektedir.

\section{Şekil 1. Türkiye'de 1925-2018 döneminde sigara iç satışı (milyar adet)}

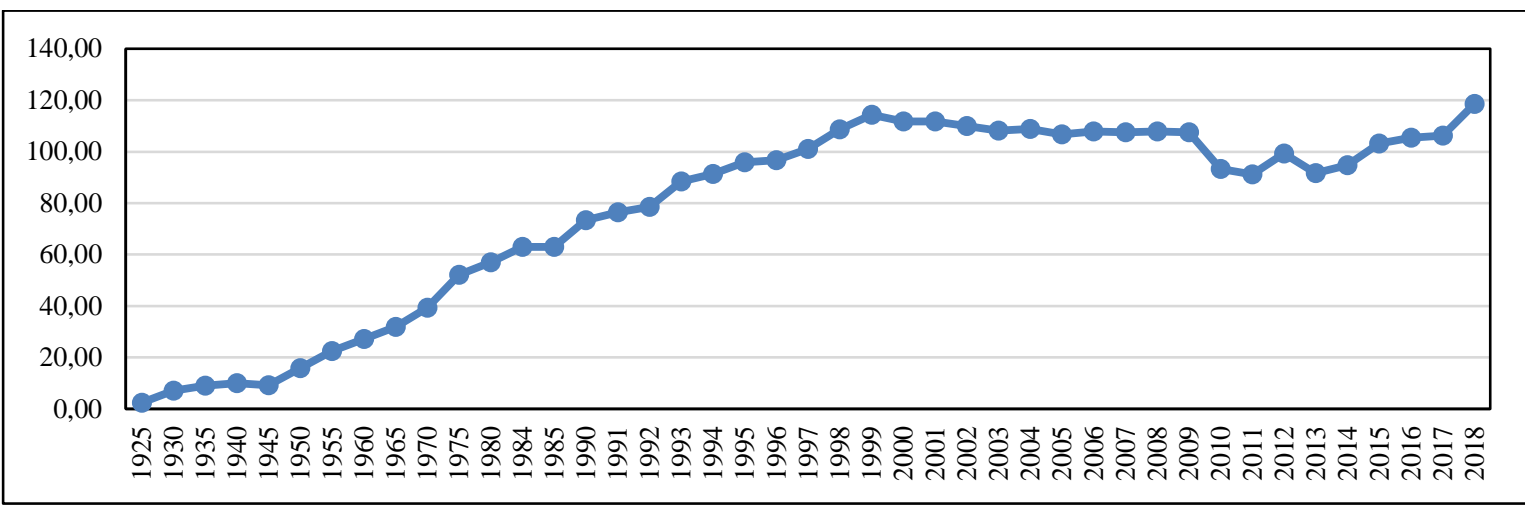

Kaynak: T.C. Tarım ve Orman Bakanlığı Tütün ve Alkol Dairesi Başkanlığı (2018).

\subsection{Yetişkinlerde Tütün Tüketimi}

Türkiye'de yetişkinlerin tütün tüketimine ilişkin yapılan ilk çalışmalar arasında yer alan "1988 Sigara alışkanlıkları ve sigara ile mücadele kampanyası kamuoyu araştırma raporu”nda 15 ve üzeri yaş grubunda ülkeyi temsil eden örneklem temel alınmış; tütün tüketim oranı yetişkinlerin genelinde \%44, erkeklerde \%62,8 ve kadınlarda \%24,3 olarak belirtilmiştir. "1993 Türkiye’de Sağlık Hizmetlerinin Kullanımı Araştırması"na göre ise tütün tüketim oranı 18 yaş ve üzerindeki yetişkinlerin genelinde $\% 33,6$; erkeklerde $\% 57,8$ ve kadınlarda ise $\% 13,5$ olarak gerçekleşmiştir. Ayrıca, 18 yaş ve üzerindeki bireyleri ele alan diğer iki çalışmadan "2003 Türkiye: Hastalık Yükü ve Maliyet Etkinlik Çalışması" verilerine göre yetişkinlerin genelinde $\% 33,8$; erkeklerde $\% 52,9$ ve kadınlarda ise $\% 19,5$ oranında tütün tüketimine rastlanırken "2006 Türkiye Aile Yapısı Araştırması ” bulguları ise yetişkinlerin genelinde \%33,4; erkeklerde \%50,6 ve kadınlarda \%16,6 oranında tütün tüketildiğini göstermektedir (Bilir vd., 2009: 19-20). Bu bulgular 1şığında, Türkiye'de 1988-2006 döneminde tütün tüketim oranının gerek yetişkinlerin geneli, gerekse erkekler ve kadınlar ayrı ayrı ele alındığında azalış trendi sergilediğini ve erkeklerin tütün tüketim oranının kadınlarınkinin oldukça üzerinde olduğunu ifade etmek mümkündür. 
Türkiye'de 1988-2006 döneminde yetişkinlerin tütün tüketim davranışına ilişkin önemli bulgular veren söz konusu çalışmaların ardından, 2008, 2012 ve 2016 yıllarında MPOWER politika paketinin "M (MONITOR): Tütün kullanımını izle" ilkesine uygun bir biçimde KYTA (Küresel Yetişkin Tütün Araştırması, GATS), gerçekleştirilmiştir. 15 yaş ve üzerindeki yetişkinlerin tütün tüketim durumlarına ilişkin KYTA bulgularının yer aldığı Tablo 4'e göre 2008 yılında, tütün tüketim oranı (halen) yetişkinlerin genelinde $\% 31,2$; erkeklerde $\% 47,9$ ve kadınlarda \%15,2 olarak gerçekleşmiştir. Yaş grupları ele alındığında ise en düşük oran \%10,3 ile 65+ yaş grubunda ve en yüksek oran ise \%39,9 ile 25-44 yaş grubunda gerçekleşmiştir. Yerleşim yeri ele alındığında, 2008 yılında tütün tüketimi, kentsel alanda \%33,0 ve kırsal alanda \%27,2 oranında gerçekleşmiştir. KYTA 2012 verileri ise yetişkinlerin genelinde \%27,1; erkeklerde \%41,5 ve kadınlarda $\% 13,1$ oranında tütün tüketiminin gerçekleştiğini vurgulamaktadır. Söz konusu yılda en düşük oranda tüketimin gerçekleştiği grup \%8,8 ile 65+ yaş grubu ve en yüksek oranda tüketimin gerçekleştiği grup ise \%35,7 ile 25-44 yaş grubu olmuştur. 2012 yılı bulguları yerleşim yeri boyutunda ele alındığında, tütün tüketimi kentsel alanda \%29,0 ve kırsal alanda \%22,0 oranında gerçekleşmiştir. KYTA 2016, tütün tüketiminin yetişkinlerde \%31,6; erkeklerde \%44,1 ve kadınlarda \%19,2 oranında gerçekleştiğini göstermektedir. Tütün tüketimi, yaş grupları çerçevesinde ele alındığında, en düşük oranda tüketimi \%10,9 ile $65+$ yaş grubunun ve en yüksek oranda tüketimi \%37,0 ile 25-44 yaş grubunun gerçekleştiği görülmektedir. Yerleşim yeri söz konusu olduğunda ise tütün tüketimi, kentsel alanda \%32,1 ve kırsal alanda \%25,5 oranında gerçekleşmiştir. KYTA’nın 2008, 2012 ve 2016 bulguları 1şığında, erkeklerin, 25-44 yaş grubundaki bireylerin ve kentsel alanda yaşayanların diğerlerine göre daha yüksek oranda tütün tükettiklerini söylemek yerinde olacaktır.

Söz konusu bulguların yanı sıra bireylerin tütün tüketim durumunu detaylı bir biçimde (halen, her gün ve ara sıra) ele alan Tablo 4'e göre halen tütün tüketen yetişkinlerin çok büyük oranda her gün tütün tüketen yetişkinlerden oluştuğunu söylemek yerinde olacaktır. Her gün tütün tüketen yetişkinlerin oranı 2008 yılında \%27,4 iken 2012 yılında \%23,8'e gerilemiş olmasına rağmen sonrasında artış kaydederek 2016 yılında \%29,6 olarak gerçekleşmiştir. Her gün tütün tüketme davranışı dalgalı bir seyir izleyerek erkeklerde 2008 yılında $\% 43,8 ; 2012$ y1lında \%37,3 ve 2016 yılında \%41,8 oranında gerçekleşirken kadınlarda ise bu oran söz konusu yıllarda sırasıyla \%11,6; \%10,7 ve \%17,5 olarak gerçekleşmiştir. Her gün tütün tüketme davranışı, yaş grupları açısından ele alındığında, 2008-2016 döneminin tamamında her gün tütün tüketme davranışı en düşük oranla 65+ yaş grubunda ve en yüksek oranla 25-44 yaş grubunda 
gerçekleşmiştir. Bahsi geçen diğer demografik özellikler için geçerli olan dalgalı trend yerleşim yeri değişkeni açısından da etkili olmuş ve her gün tütün tüketme davranışı kentsel alanda 2008 yılında \%29,0; 2012 yılında \%25,7 ve 2016 yılında \%30,1; kırsal alanda ise söz konusu yıllarda sırasıyla \%23,9; \%18,9 ve \%23,7 oranında gerçekleşmiştir.

Tablo 4'ün işaret ettiği bulgular, ara sıra tütün tüketme davranışının 2008-2016 döneminde yetişkinlerin genelinde $\% 3,8$ 'den $\% 2,0$ 'a, erkeklerde $\% 4,1$ 'den $\% 2,3$ 'e ve kadınlarda ise \%3,6'dan \%1,7'ye gerilediğini işaret etmektedir. Yaş grupları ele alındığında 2008-2016 döneminin tamamında, her gün tütün tüketme davranışında olduğu gibi ara sıra tütün tüketme davranışında da en düşük oran 65+ yaş grubundaki bireyler ve en yüksek oran 25-44 yaş grubundaki bireyler tarafından gerçekleştirilmiştir. Yerleşim yeri ve ara sıra tütün tüketme davranışı birlikte ele alındığında, kentsel alanda ara sıra tütün tüketme davranışının 2008 yılındaki \%4,1'den 2016 yılında \%2,0'a; kırsal alanda ara sıra tütün tüketme davranışının ise 2008 yılındaki \%3,3’den 2016 yılında \%1,9'a gerilediği görülmektedir.

Tablo 4: Halen, her gün ve ara sıra tütün tüketen yetişkinlerin cinsiyet, yaş grubu ve yerleşim yerine göre yüzde dağılımı (\%)

\begin{tabular}{|c|c|c|c|c|c|c|c|c|c|c|}
\hline \multirow{3}{*}{\multicolumn{2}{|c|}{$\begin{array}{l}\text { Demografik } \\
\text { Özellikler }\end{array}$}} & \multicolumn{9}{|c|}{ Tütün tüketim durumu } \\
\hline & & \multicolumn{3}{|c|}{2008 KYTA } & \multicolumn{3}{|c|}{2012 KYTA } & \multicolumn{3}{|c|}{2016 KYTA } \\
\hline & & Halen & Hergün & $\begin{array}{l}\text { Ara } \\
\text { sira }\end{array}$ & Halen & Hergün & $\begin{array}{l}\text { Ara } \\
\text { sira }\end{array}$ & Halen & Hergün & Ara sıra \\
\hline \multicolumn{2}{|l|}{ Toplam } & 31,2 & 27,4 & 3,8 & 27,1 & 23,8 & 3,3 & 31,6 & 29,6 & 2,0 \\
\hline \multirow[t]{2}{*}{ Cinsiyet } & Erkek & 47,9 & 43,8 & 4,1 & 41,5 & 37,3 & 4,1 & 44,1 & 41,8 & 2,3 \\
\hline & Kadın & 15,2 & 11,6 & 3,6 & 13,1 & 10,7 & 2,4 & 19,2 & 17,5 & 1,7 \\
\hline \multirow{4}{*}{$\begin{array}{l}\text { Yaş } \\
\text { grubu }\end{array}$} & $15-24$ & 25,3 & 21,7 & 3,6 & 20,0 & 16,9 & 3,1 & 31,9 & 29,8 & 2,0 \\
\hline & $25-44$ & 39,9 & 34,7 & 5,2 & 35,7 & 31,4 & 4,3 & 37,0 & 34,7 & 2,3 \\
\hline & $45-64$ & 29,5 & 27,0 & 2,5 & 25,9 & 23,2 & 2,7 & 31,6 & 29,6 & 2,1 \\
\hline & $65+$ & 10,3 & 8,7 & 1,6 & 8,8 & 7,9 & 0,9 & 10,9 & 10,2 & 0,7 \\
\hline \multirow{2}{*}{$\begin{array}{l}\text { Yerleşim } \\
\text { yeri }\end{array}$} & Kentsel & 33,0 & 29,0 & 4,1 & 29,0 & 25,7 & 3,3 & 32,1 & 30,1 & 2,0 \\
\hline & Kursal & 27,2 & 23,9 & 3,3 & 22,0 & 18,9 & 3,1 & 25,5 & 23,7 & 1,9 \\
\hline
\end{tabular}

Kaynak: CDC (2019b). 
Saraçoğlu S., Öztürk F. (2020), “Türkiye'de Tütün Kontrol Politikaları ve Tütün Tüketimi Üzerine Bir Değerlendirme”, Politik Ekonomik Kuram, Cilt 4(1)

Tablo 5: Yetişkinlerde günde tüketilen sigara sayısı ortalamasının cinsiyet, yaş grubu ve yerleşim yerine göre dağılımı

\begin{tabular}{|c|c|c|c|c|}
\hline \multicolumn{2}{|c|}{ Demografik Özellikler } & 2008 KYTA & 2012 KYTA & 2016 KYTA \\
\hline \multicolumn{2}{|l|}{ Toplam } & 17,7 & 19,2 & 18,0 \\
\hline \multirow[t]{2}{*}{ Cinsiyet } & Erkek & 19,3 & 20,3 & 18,9 \\
\hline & Kadın & 12,2 & 15,3 & 15,8 \\
\hline \multirow{4}{*}{$\begin{array}{l}\text { Yaş } \\
\text { grubu }\end{array}$} & $15-24$ & 16,2 & 18,1 & 16,4 \\
\hline & $25-44$ & 17,3 & 18,9 & 18,0 \\
\hline & 45-64 & 19,8 & 20,6 & 19,3 \\
\hline & $65+$ & 18,1 & 17,1 & 17,5 \\
\hline \multirow{2}{*}{$\begin{array}{l}\text { Yerleşim } \\
\text { yeri }\end{array}$} & Kentsel & 17,1 & 18,9 & 18,0 \\
\hline & Kırsal & 19,6 & 20,0 & 17,8 \\
\hline
\end{tabular}

Kaynak: CDC (2019b).

Tablo 5'de gösterildiği ve KYTA bulgularının işaret ettiği üzere yetişkinlerin genelinde günde tüketilen sigara sayısı ortalaması 2008 yılında 17,7; 2012 yılında 19,2 ve 2016 yılında 18,0 adet olarak gerçekleşmiştir. Erkeklerde günde tüketilen sigara sayısı ortalaması 2008 yılında 19,3; 2012 yılında 20,3 ve 2016 yılında 18,9 adet olarak gerçekleşirken kadınlarda günde tüketilen sigara sayısı ortalaması 2008 yılında 12,2; 2012 y1lında 15,3 ve 2016 y1lında 15,8 adet olarak gerçekleşmiştir. 2008-2016 döneminin tamamında, erkeklerin günlük sigara tüketim miktarı genel ortalamanın üzerinde kadınlarınki ise genel ortalamanın altında seyretmiştir. Yaş grupları ele alındığında, 2008-2016 döneminin tamamında, 45-64 yaş grubundaki bireyler genel ortalamanın üzerinde günde tüketilen sigara sayısı ortalamasına ulaşmış ve en yüksek düzeyde sigara tüketen yaş grubu olmuştur. Yerleşim yeri ele alındığında kentsel alanda günde tüketilen sigara sayısı ortalaması 2008 yılında 17,1; 2012 yılında 18,9 ve 2016 yılında 18,0 olarak gerçekleşirken kırsal alanda bu ortalama söz konusu yıllarda sırasıyla 19,6; 20,0 ve 17,8 adet olarak gerçekleşmiştir. Kentsel alanda günde tüketilen sigara sayısı ortalaması 2008 ve 2012 yıllarında genel ortalamanın altında söz konusu yıllarda kırsal alandaki sigara tüketimi ise genel ortalamanın üzerinde seyretmiştir. Diğer taraftan, 2016 yılında kentsel alandaki sigara tüketimi genel ortalama ile eşit düzeyde iken kırsal alandaki sigara tüketimi ise genel ortalamanın altında gerçekleşmiştir.

KYTA bulgularının yer aldığı Tablo 6'da gösterildiği üzere; halen mamul sigara tüketen yetişkinlerin genelinde aylık ortalama sigara harcaması 2008 yılında 80,6 TL; 2012 yılında 146,1 TL ve 2016 yılında 269,4 TL olarak gerçekleşmiştir. Cinsiyete göre ele alındığında erkeklerde aylık ortalama sigara harcaması 2008 yılında 88,4 TL; 2012 yılında 157,6 TL ve 2016 yılında 286,1 TL olarak gerçekleşirken bu harcama kadınlarda söz konusu yıllarda sırasıyla 52,5 TL; 110,0 TL ve 232,4 TL olarak gerçekleşmiştir. 2008-2016 döneminin 
tamamında erkeklerin aylık sigara harcaması genel ortalamanın üzerinde kadınlarınki ise genel ortalamanın altında seyretmiş ve aylık harcama açısından cinsiyet farklılıkları belirgin bir biçimde kendini göstermiştir. Yaş grupları ele alındığında, aylık sigara harcaması açısından 4564 yaş grubundaki bireyler 2008-2016 döneminin tamamında en yüksek düzeyde harcama yapan yaş grubu olmuştur. 45-64 yaş grubundaki bireyler tarafindan yapılan aylık sigara harcaması 2008 y1lında 86,6 TL; 2012 yılında 158,1 TL ve 2016 y1lında 282,0 TL tutarında iken dönemin tamamında bu alanda en düşük harcama, 65+yaş grubundaki bireyler tarafından söz konusu yıllarda sırasıyla 66,3 TL; 114,5 TL ve 230,3 TL olarak gerçekleştirilmiştir. Yerleşim yeri çerçevesinden konuya bakıldığında, 2008-2016 döneminin tamamında kentsel alanda yaşayan bireylerin kırsal alanda yaşayan bireylere göre daha fazla aylık sigara harcaması yaptıkları açıkça görülmektedir.

Tablo 6: Halen mamul sigara tüketen yetişkinlerde sigara harcaması ve ortalama fiyatlarının cinsiyet, yaş grubu ve yerleşim yerine göre dağılımı

\begin{tabular}{|c|c|c|c|c|c|c|c|}
\hline \multirow{2}{*}{\multicolumn{2}{|c|}{$\begin{array}{l}\text { Demografik } \\
\text { Özellikler }\end{array}$}} & \multicolumn{2}{|l|}{2008 KYTA } & \multicolumn{2}{|c|}{2012 KYTA } & \multicolumn{2}{|c|}{2016 KYTA } \\
\hline & & $\begin{array}{l}\text { Aylık sigara } \\
\text { harcaması }\end{array}$ & $\begin{array}{l}20 \text { mamul } \\
\text { sigaranın } \\
\text { ortalama } \\
\text { fiyatı }\end{array}$ & $\begin{array}{l}\text { Aylık } \\
\text { sigara } \\
\text { harcaması }\end{array}$ & $\begin{array}{l}20 \text { mamul } \\
\text { sigaranın } \\
\text { ortalama } \\
\text { fiyatı }\end{array}$ & $\begin{array}{l}\text { Aylık } \\
\text { sigara } \\
\text { harcaması }\end{array}$ & $\begin{array}{l}20 \text { mamul } \\
\text { sigaranın } \\
\text { ortalama } \\
\text { fiyatı }\end{array}$ \\
\hline \multicolumn{2}{|l|}{ Toplam } & 80,6 & 3,3 & 146,1 & 5,7 & 269,4 & 10,5 \\
\hline \multirow[t]{2}{*}{ Cinsiyet } & Erkek & 88,4 & 3,3 & 157,6 & 5,7 & 286,1 & 10,5 \\
\hline & Kadın & 52,5 & 3,1 & 110,0 & 5,4 & 232,4 & 10,6 \\
\hline \multirow{4}{*}{$\begin{array}{l}\text { Yaş } \\
\text { grubu }\end{array}$} & $15-24$ & 75,2 & 3,4 & 127,9 & 5,6 & 252,4 & 10,7 \\
\hline & $25-44$ & 80,5 & 3,4 & 148,0 & 5,7 & 273,2 & 10,6 \\
\hline & $45-64$ & 86,6 & 3,1 & 158,1 & 5,7 & 282,0 & 10,5 \\
\hline & $65+$ & 66,3 & 2,7 & 114,5 & 5,2 & 230,3 & 9,3 \\
\hline \multirow{2}{*}{$\begin{array}{l}\text { Yerleşim } \\
\text { yeri }\end{array}$} & Kentsel & 82,1 & 3,3 & 148,1 & 5,7 & 270,7 & 10,6 \\
\hline & Kırsal & 80,0 & 3,1 & 139,2 & 5,5 & 251,0 & 10,2 \\
\hline
\end{tabular}

Kaynak: CDC (2019b).

Tablo 6 ayrıca, 20 mamul sigaranın ortalama fiyatının 2008 yılında 3,3 TL; 2012 yılında 5,7 TL ve 2016 yılında 10,5 TL olarak gerçekleştiğini işaret etmektedir. 20 mamul sigaranın ortalama fiyatı cinsiyet çerçevesinden ele alındığında, erkeklerde 2008-2016 döneminin tamamında genel ortalamaya eşit bir biçimde gerçekleşirken kadınlar açısından 2008 ve 2012 yıllarında genel ortalamanın altında, 2016 yılında ise genel ortalamanın üzerinde gerçekleşmiştir. Yaş grubu söz konusu olduğunda, 2008-2016 döneminin tamamında 65+ yaş grubundaki bireylerde 20 mamul sigaranın ortalama fiyatı belirgin bir biçimde genel ortalamanın altında gerçekleşirken diğer yaş gruplarındaki bireylerde fiyat genel ortalamanın 
Saraçoğlu S., Öztürk F. (2020), “Türkiye'de Tütün Kontrol Politikaları ve Tütün Tüketimi Üzerine Bir Değerlendirme”, Politik Ekonomik Kuram, Cilt 4(1)

etrafında oluşmaktadır. Yerleşim yeri açısından konu ele alındığında, 2008-2016 döneminin tamamında kentsel alanda yaşayan bireylerin kırsal alanda yaşayan bireylere göre daha yüksek ortalama sigara fiyatıyla karşılaştıkları görülmektedir.

Tablo 7: 20-34 yaş aralığındaki yetişkinlerde her gün sigara tüketmeye başlama yaşı ortalamasının cinsiyet ve yerleşim yerine göre dağılımı

\begin{tabular}{|l|l|l|l|l|}
\hline \multicolumn{2}{|l|}{ Demografik Özellikler } & 2008 KYTA & 2012 KYTA & 2016 KYTA \\
\hline \multicolumn{2}{|l|}{ Toplam } & 17,1 & 17,2 & 17,2 \\
\hline \multirow{2}{*}{ Cinsiyet } & Erkek & 16,7 & 16,9 & 16,9 \\
\cline { 2 - 5 } & Kadın & 17,9 & 18,1 & 17,8 \\
\hline \multirow{2}{*}{ Yerleşim yeri } & Kentsel & 17,2 & 17,1 & 17,2 \\
\cline { 2 - 5 } & Kırsal & 16,5 & 17,3 & 17,0 \\
\hline
\end{tabular}

Kaynak: CDC (2019b).

Tablo 7'ye göre 20-34 yaş aralığındaki yetişkinlerde her gün sigara tüketmeye başlama yaşı ortalaması 2008 yılında 17,1 yıl; 2012 ve 2016 yıllarında ise 17,2 yıl olarak gerçekleşmiştir. Söz konusu ortalama cinsiyet bağlamında ele alındığında erkeklerde 2008 yılında 16,7 yıl; 2012 ve 2016 yıllarında 16,9 yıl olarak gerçekleşirken kadınlarda ise söz konusu yıllarda sırasıyla 17,9 yıl; 18,1 yıl ve 17,8 yıl olarak gerçekleşmiştir. Buradan hareketle, 2008-2016 döneminin tamamında erkeklerin genel ortalamadan daha erken bir yaşta; kadınların ise genel ortalamadan daha geç bir yaşta sigara tüketmeye başladıklarını ifade etmek mümkündür. 20-34 yaş aralığındaki yetişkinlerde her gün sigara tüketmeye başlama yaşı ortalaması yerleşim yeri boyutunda incelendiğinde ise kentsel alanda yaşayan bireylerde 2008 ve 2016 yıllarında 17,2 ve 2012 y1lında 17,1 olarak gerçekleşirken kırsal alanda yaşayan bireylerde ise 2008 yılında 16,5; 2012 yılında 17,3 ve 2016 yılında 17,0 olarak gerçekleşmiştir.

\subsection{Yetişkinlerde Tütün Tüketimini Bırakma Davranışı}

Türkiye'de yetişkinlerin tütün tüketimini bırakma davranışının yapısını, 2008 KYTA, 2012 KYTA ve 2016 KYTA bulguları yardımıyla ele almak mümkündür. Tablo 8'de gösterildiği ve KYTA bulgularının işaret ettiği üzere yetişkinlerin genelinde sigara tüketimini bırakma girişimi 2008 y1lında \%44,8; 2012 y1lında \%46,0 ve 2016 yılında \%24,6 olarak gerçekleşmiştir. Erkeklerde sigara tüketimini bırakma girişimi 2008 yılında \%44,1; 2012 yılında \%45,1 ve 2016 yılında \%26,2 olarak gerçekleşirken bu oran kadınlarda söz konusu yııllarda sırasıyla \%46,9; $\% 48,8$ ve $\% 20,8$ olarak gerçekleşmiştir. $\mathrm{Bu}$ istatistiklerde dikkate değer iki nokta bulunmaktadır. Bunlardan ilki, gerek yetişkinlerin geneli gerekse erkek ve kadınlar açısında ayrı ayrı ele alındığında sigara tüketimini bırakma girişiminde 2008-2012 döneminde bir artış ve 2012-2016 döneminde keskin bir azalışın yaşandığıdır. Dikkate değer bir diğer nokta ise, erkeklerin 2008 ve 2012 y1llarında genel ortalamanın altında ve 2016 y1lında genel ortalamanın 
Saraçoğlu S., Öztürk F. (2020), “Türkiye'de Tütün Kontrol Politikaları ve Tütün Tüketimi Üzerine Bir Değerlendirme”, Politik Ekonomik Kuram, Cilt 4(1)

üstünde; kadınların ise tam aksi bir eğilim göstererek 2008 ve 2012 yıllarında genel ortalamanın üstünde ve 2016 yılında ise genel ortalamanın altında bir oranda sigara tüketimini bırakma girişiminde bulunmalarıdır. Yaş grupları ele alındığında, 2008 yılında 15-24 yaş grubunun; 2012 y1lında 25-44 yaş grubunun ve 2016 yılında ise $65+$ yaş grubunun en yüksek oranda sigara tüketimini bırakma girişiminde bulunduklarını belirtmek mümkündür. Yerleşim yeri ele alındığında kentsel alanda sigara tüketimini bırakma girişimi 2008 yılında \%44,7; 2012 yılında $\% 46,5$ ve 2016 yılında \%24,0 olarak gerçekleşirken kırsal alanda bu oran söz konusu yıllarda sırasıyla \%45,1; \%44,3 ve \%33,3 olarak gerçekleşmiştir. Buradan hareketle, sigara tüketimini bırakma girişimi 2008 ve 2016 yıllarında kırsal alanda; 2012 yılında ise kentsel alanda daha yüksek oranda gerçekleşmiştir.

Tablo 8: Son 12 ayda sigara tüketen yetişkinlerden sigara tüketimini bırakma girişiminde bulunanların cinsiyet, yaş grubu ve yerleşim yerine göre dağılımı (\%)

\begin{tabular}{|l|l|l|l|l|}
\hline \multicolumn{2}{|l|}{ Demografik Özellikler } & \multicolumn{2}{l}{ Sigara tüketimini bırakma girişimi yapan } \\
\cline { 3 - 5 } \multicolumn{2}{|l|}{} & $\mathbf{2 0 0 8}$ KYTA & $\mathbf{2 0 1 2}$ KYTA & $\mathbf{2 0 1 6}$ KYTA \\
\hline Toplam & 44,8 & 46,0 & 24,6 \\
\hline Cinsiyet & Erkek & 44,1 & 45,1 & 26,2 \\
\cline { 2 - 5 } & Kadın & 46,9 & 48,8 & 20,8 \\
\hline \multirow{3}{*}{ Yaş grubu } & $\mathbf{1 5 - 2 4}$ & 52,3 & 40,2 & 17,2 \\
\cline { 2 - 5 } & $\mathbf{2 5 - 4 4}$ & 42,7 & 48,3 & 23,9 \\
\cline { 2 - 5 } & $\mathbf{4 5 - 6 4}$ & 44,2 & 44,8 & 30,6 \\
\cline { 2 - 5 } & $\mathbf{6 5 +}$ & 40,6 & 47,1 & 31,5 \\
\hline Yerleşim yeri & Kentsel & 44,7 & 46,5 & 24,0 \\
\cline { 2 - 5 } & Krsal & 45,1 & 44,3 & 33,3 \\
\hline
\end{tabular}

Kaynak: CDC (2019b).

\subsection{Gençlerde Tütün Tüketimi}

Tütün tüketimine başlama açısından kritik bir dönemi işaret eden gençler, tütün endüstrisi açısından potansiyel tüketiciler konumunda bulunduğundan söz konusu grubun tütün tüketim davranışının incelenmesi büyük önem taşımaktadır. Türkiye'de gençlerin tütün tüketimine ilişkin ilk çalışmalar genellikle il düzeyinde ve okullarda yapılmış, söz konusu çalışmalarda 13-15 yaş arası gençlerde tütün tüketim oranı \%0,9 ile \% $\%, 1$ arasında değişen değerler almıştır (Bilir vd., 2010: 23).

Türkiye'de gençlerin tütün tüketimi davranışına ilişkin önemli bulgular veren söz konusu çalışmaların ardından MPOWER politika paketinin "M (MONITOR): Tütün kullanımını izle" ilkesine uygun bir biçimde 2003, 2009, 2012 ve 2017 yıllarında KGTA (Küresel Gençlik Tütün Araştırması, GYTS) gerçekleştirilmiştir. Gençlere odaklanan, okul tabanlı ve ulusal düzeyde 
Saraçoğlu S., Öztürk F. (2020), “Türkiye'de Tütün Kontrol Politikaları ve Tütün Tüketimi Üzerine Bir Değerlendirme”, Politik Ekonomik Kuram, Cilt 4(1)

temsiliyete sahip bir araştırma olan KGTA'nın bulgularının yer aldığı Tablo 9'a göre, gençlerin genelinde en az bir defa sigara tüketmeyi deneyenlerin oranı 2003 yılında \%26,3; 2009 yılında \%29,6; 2012 yılında \%32,4 ve 2017 y1lında ise \%28,0 olarak gerçekleşmiştir. Söz konusu oran gençler arasında erkeklerde 2003 yılında \%31,7; 2009 yılında \%32,3; 2012 yılında \%36,2 ve 2017 yılında ise \%32,9 olarak gerçekleşirken kadınlarda ise söz konusu y1llarda sirasıyla \%19,7; \%25,4; \%26,9 ve 23,0 olarak gerçekleşmiştir. Buradan hareketle, 2003-2017 döneminin tamamında gençler arasında erkekler genel ortalamadan daha yüksek bir oranda; kadınlar ise genel ortalamadan daha düşük bir oranda en az bir defa sigara tüketmeyi denemişlerdir.

Tablo 9'un bulguları ayrıca, gençlerin genelinde halen tütün ürünü tüketenlerin oranının 2003 y1lında \%8,4; 2009 y1lında \%11,9; 2012 y1lında \%16,8 ve 2017 y1lında \%17,9 olarak gerçekleştiğini işaret etmektedir. Analize konu olan oran gençler arasında erkeklerde 2003 yılında \%11,1; 2009 yılında \%14,4; 2012 yılında \%20,3 ve 2017 yılında \%23,2 olarak gerçekleşirken bu oran kadınlarda söz konusu yıllarda sırasıyla \%4,4; \%7,4; \%12,8 ve \%12,1 olarak gerçekleşmiştir. Gençler arasında en az bir defa sigara tüketmeyi deneyenlerin oranında olduğu gibi, burada da 2003-2017 döneminin tamamında erkekler genel ortalamadan daha yüksek bir oranda; kadınlar ise genel ortalamadan daha düşük bir oranda halen tütün ürünü tüketmektedir. KGTA bulguları ayrıca, gençler arasında halen sigara tüketme oranının 2003 y1lında \%6,9; 2009 y1lında \%8,4; 2012 y1lında \%10,4 ve 2017 y1lında \%7,7 olarak gerçekleştiğini vurgulamaktadır. Bu oran erkeklerde 2003 yılında \%9,4; 2009 y1lında \%10,2; 2012 yılında \%12,1ve 2017 y1lında \%9,9 olarak gerçekleşirken kadınlarda ise söz konusu y1llarda sırasıyla $\% 3,5 ; \% 5,3 ; \% 8,3$ ve $\% 5,3$ biçiminde gerçekleşmiştir. Gençlerin tütün tüketimine ilişkin söz konusu diğer iki göstergede olduğu gibi burada da 2003-2017 döneminin tamamında erkekler genel ortalamadan daha yüksek bir oranda; kadınlar ise genel ortalamadan daha düşük bir oranda halen sigara tüketmektedir.

Tablo 9: 13-15 yaş aralığındaki gençlerde tütün tüketim durumu (\%)

\begin{tabular}{|c|c|c|c|c|c|c|c|c|c|}
\hline \multirow{2}{*}{$\begin{array}{l}\text { Tütün } \\
\text { tüketim } \\
\text { durumu }\end{array}$} & \multicolumn{3}{|c|}{$\begin{array}{l}\text { En az bir defa sigara } \\
\text { tüketmeyi deneyenler }\end{array}$} & \multicolumn{3}{|c|}{$\begin{array}{l}\text { Halen tütün ürünü } \\
\text { tüketenler }\end{array}$} & \multicolumn{3}{|c|}{ Halen sigara tüketenler } \\
\hline & Erkek & Kadın & Toplam & Erkek & Kadın & Toplam & Erkek & Kadın & Toplam \\
\hline $\begin{array}{l}2003 \\
\text { KGTA }\end{array}$ & 31,7 & 19,7 & 26,3 & 11,1 & 4,4 & 8,4 & 9,4 & 3,5 & 6,9 \\
\hline $\begin{array}{l}2009 \\
\text { KGTA } \\
\end{array}$ & 32,3 & 25,4 & 29,6 & 14,4 & 7,4 & 11,9 & 10,2 & 5,3 & 8,4 \\
\hline $\begin{array}{l}2012 \\
\text { KGTA } \\
\end{array}$ & 36,2 & 26,9 & 32,4 & 20,3 & 12,8 & 16,8 & 12,1 & 8,3 & 10,4 \\
\hline $\begin{array}{l}2017 \\
\text { KGTA } \\
\end{array}$ & 32,9 & 23,0 & 28,0 & 23,2 & 12,1 & 17,9 & 9,9 & 5,3 & 7,7 \\
\hline
\end{tabular}

Kaynak: CDC (2019b). 


\section{Sonuç}

1950’li ve 1960'lı yıllarda tütün tüketiminin bireylerin sağlığı üzerindeki zararlı etkilerini ele alan çalışmaların yayımlanmasıyla birlikte tütün tüketimine bakış büyük ölçüde değişmiş, 1980'li yılların sonunda bireylerin tütün kullanımından pasif etkileniminin hastalıklara ve ölümlere yol açtığına ilişkin yeni bulguların ortaya çıkması ise tütün kontrol politikalarında önemli bir değişimin habercisi olmuştur. Bu gelişmelere rağmen 1990'lı yılların başlarına kadar tütün üretimini destekleyen $\mathrm{DB}$, tütünün küresel düzeyde yarattı̆̆1 maliyetin elde edilen kazançtan daha büyük olduğu ve devletin tütün tüketimini azaltmaya yönelik müdahalelerinin toplumsal refahı artıracağı gerekçelerinden hareketle 1990'lı yılların ortasından itibaren tütün kontrolü ile ilgili yeni bir iktisadi yaklaşım benimseye başlamıştır. DSÖ ise küresel düzeyde bir tütün kontrol politikası çerçevesi oluşturmaya yönelik çalışmalarını hızlandırmış ve 2003 yılında temel politika önerilerinin tütün talebini ve arzını azaltıcı önlemler olduğu TKÇS kabul edilmiştir. DSÖ, 2008 yılında TKÇS’ye taraf olan ülkelere rehber olması amacıyla, “izle, koru, öner, uyar, yasakla ve vergilendir” stratejilerini içeren MPOWER politika paketini hazırlamıştır. Buradan hareketle, DB ve DSÖ önderliğinde yürütülen çalışmalarla birlikte dünya genelinde tütün kontrol politikalarına verilen önemin özellikle 1990'lı yıllardan itibaren $\operatorname{arttığını~ifade~etmek~yerinde~olacaktır.~}$

Türkiye'de ise 1980'li y1llara kadar “TEKEL”'in denetimde olan tütün sektörü, 1980'li yıllarında başında liberal iktisadi politikaların benimsenmesiyle birlikte uluslararası tütün şirketlerinin faaliyetlerine açılmış ve bu şirketlerin reklam vb. uygulamalarının artması, tütün tüketiminin hızlı bir biçimde yükselmesine yol açmıştır. Bu hızlı yükseliş, tütün kontrolüne yönelik girişimlerin 1980'li yılların sonlarında başlamasına yol açmış ve bu çalışmaların sonucunda “Tütün Mamullerinin Zararlarının Önlenmesine Dair 4207 Sayılı Kanun” 1996 yılında yürürlüğe girmiştir. TKÇS'nin 2004 yılında Türkiye tarafından imzalanarak uygulamaya konulmasıyla birlikte, 4207 Sayılı Kanun'un TKÇS ile uyumlu hale getirilmesine yönelik çalışmalara başlanmış ve bu çalışmaların neticesinde, "5727 sayılı Tütün Ürünlerinin Zararlarının Önlenmesi ve Kontrolü Hakkında Kanun” 2008 y1lında yürürlüğe girmiştir. Türkiye'de 1960-2000 yılları arasındaki dönemde neredeyse 4 katına çıkan sigara tüketimi, bahsi geçen kanunların yürürlüğe girmeleriyle birlikte önce durmuş, bir süre yatay olarak seyretmiş; 2009-2011 döneminde ise azalış trendine girmiştir. 5727 sayılı kanunun yürürlüğe girmesini takip eden yıllarda birçok düzenlemenin hayata geçirilmesiyle birlikte Türkiye 2013 y1lında MPOWER stratejilerinin tümünü uygulayan ilk ve 2019 yılında MPOWER stratejilerinin tamamının yerine getiren iki ülkeden biri olmuştur. Diğer taraftan, Türkiye'de 
tütün tüketimi, 2013 ve sonrasında ise keskin bir artış göstererek 2018 yılında, 2000 yılındaki düzeyine ulaşmıştır. $\mathrm{Bu}$ artış eğilimi, söz konusu dönemde tütün kontrolüne yönelik hayata geçirilen uygulamaların tütün kontrolünü etkin bir biçimde sağlayamadığını gözler önüne sermektedir.

Türkiye'de 2008, 2012 ve 2016 yıllarında yapılan KYTA bulgularına göre, tütün tüketim oranı 2008-2012 döneminde azalış kaydetmesine rağmen 2012-2016 döneminde ise artış kaydetmiştir. Bu duruma, 5727 Sayılı Kanun'un etkilerinin yakından hissedildiği 2008-2012 döneminde tütün tüketim oranında azalış yaşandığı, diğer taraftan tütün kontrolü uygulamalarına bir şekilde bağışıklığın geliştirildiği 2012-2016 döneminde ise tütün tüketim oranının yükseliş eğilimi sergilediği açıklaması getirilebilir. Diğer taraftan, günde tüketilen sigara sayısı ortalaması, tütün tüketim oranının tam tersi istikamette yol almış ve 2008-2012 döneminde artış ve 2012-2016 döneminde azalış sergilemiştir. Bununla birlikte gerek tütün tüketim oranı gerekse günde tüketilen sigara sayısı ortalaması verileri açısından en riskli grup erkekler olmakla birlikte; 25-44 yaş grubu tüketim oranı açısından 45-64 yaş grubu ise günde tüketilen sigara sayısı ortalaması açısından risk grubu içerisinde yer almaktadır. Diğer taraftan, gerek ortalama sigara harcaması gerekse ortalama sigara fiyatı 2008-2016 döneminin tamamında sürekli bir biçimde artış kaydetmiştir. Bunların yanı sıra, Türkiye'de sigara tüketimine başlama yaşı yaklaşık 17 olmakla birlikte erkekler kadınlara göre daha erken bir yaşta sigara tüketimine başlamaktadır. Tütün tüketim davranışını gençler açısından inceleyen KGTA bulguları söz konusu olduğunda, tütün ürünü tüketen gençlerin oranının 2003-2017 döneminin tamamında sürekli bir biçimde arttığı ve erkeklerin kadınlara göre daha yüksek oranda tütün ürünü tükettikleri görülmektedir.

Son tahlilde tütün tüketimi ile mücadele konusunda birkaç noktanın altını çizmek yerinde olacaktır. Bilindiği üzere tütün kontrolü uygulamaları, bireylerin tütün tüketimine başlamalarını önleme ve tütün tüketimini bırakmalarını sağlamanın da aralarında olduğu birçok amacı içermektedir. Buradan hareketle, tütün tüketim oranının gerilediği 2008-2012 döneminde ilk amaç yerine getirilirken tütün tüketim oranının arttığı 2012-2016 döneminde ise ilk amaçtan sapılmıştır. Tütün tüketimi ile mücadelede 2012-2016 döneminde gerçekleşen bu istenmeyen durum, tütün tüketen bireylerin ve tütün firmalarının yasal düzenlemelere karşı geliştirdikleri bağışıklıktan kaynaklanabilir. Başta risk grubu içerisinde yer alan erkekler, 25-44 yaş grubundaki ve 45-64 yaş grubundaki bireyler olmak üzere toplumun tüm kesimleri tütünle mücadele konusunda eğitilerek sağlık bilinci oluşturulmalıdır. Bunların yanı sıra, 2003-2017 döneminin tamamında tütün tüketim oranında artışın kaydedildiği gençlerin tütün tüketimi ile 
mücadeleleri kapsamında, erken yaşlardan itibaren sigaranın olumsuz etkileri açıklanmalı ve sağlık bilinci verilmelidir. Diğer taraftan, sigara tüketimini bırakma girişiminin arttığı 20082012 döneminde ikinci amaç yerine getirilirken sigara tüketimini bırakma girişiminin azaldığ1 2012-2016 döneminde ise ikinci amaçtan sapılmıştır. Bu bağlamda, sigara tüketimini bırakma girişiminde hedeflenen düzeylere ulaşılması amacıyla sigara bırakma ünitelerine erişilebilirliğin artırılmasına ve tütün bırakma polikliniklerinin geliştirilmesine yönelik çalışmalar hızlandırılmalıdır.

\section{Kaynakça}

Aslan, D., 2010. Tütün Kontrolünde Küresel ve Ulusal Organizasyon. İçinde: Z. A. Aytemur, Ş. Akçay, ve O. Elbek, ed. Tütün ve Tütün Kontrolü Kitabı. İstanbul: Türk Toraks Derneği, 122-128.

Bilir, N., 2016. Tütün Kontrolü Çerçeve Sözleşmesi ve Türkiye: Bir Başarı Örneği. Güncel Gögüus Hastalıklarl Serisi, 4 (1), 7-12.

Bilir, N., Çakır, B., Dağlı, E., Ergüder, T. ve Önder, Z., 2009. Türkiye'de Tütün Kontrolü Politikaları. Kopenhag: Dünya Sağlık Örgütü Avrupa Bölge Ofisi.

Bilir N. ve Özcebe, H., 2011. Success story of smoke-free Turkey. Medical Journal of Islamic World Academy of Sciences, 19 (2), 59-66.

Bilir, N. ve Özcebe, H., 2013. Tobacco control activities in Turkey. Turkish Journal of Public Health, 11 (2), 96-103.

CDC, 2019a. About GTSS [online]. Available from: https://www.cdc.gov/tobacco/global/gtss/index.htm [Accessed 23 May 2019].

CDC, 2019b. Global Tobacco Surveillance System Data (GTSSData) [online]. Available from: https://nccd.cdc.gov/GTSS/rdPage.aspx?rdReport=OSH_GTSS.ExploreByLocation\&rd RequestForwarding=Form [Accessed 20 May 2019].

Doll, R. ve Hill, A. B., 1950. Smoking and carcinoma of the lung: Preliminary report. British Medical Journal, 2 (4682), 739-748.

Ergüder, T., 2010. Dünyada Tütün Kontrolü ve Dünya Sağl1k Örgütü Önerileri (MPOWER). İçinde: Z. A. Aytemur, Ş. Akçay ve O. Elbek, ed. Tütün ve Tütün Kontrolü Kitabı. İstanbul: Türk Toraks Derneği, 81-92.

Gültekin Karakaş, D. ve Y1lmaz, F., 2014. Türkiye'de Tütün Kontrolü: Sigara Vergileri ve Endüstrinin Fiyatlama Politikaları. STED/Sürekli Tıp Eğitimi Dergisi, 23 (Özel Sayı), 1823. 
Gümüş, A. ve Güler Gümüş, S., 2005. Türkiye'de Tütün Sektöründe Mevcut Uygulamalar ve Sektörün Geleceği. Tarım Ekonomisi Dergisi, 11 (1 ve 2), 81-89.

Kılınç, O. ve Günay, T., 2014. Türkiye Tütün Kontrolünde Hangi Noktada? Engeller ve Çözüm Önerileri. STED/Sürekli Tıp Ĕ̈itimi Dergisi, 23 (Özel Sayı),4-7.

Mamudu, H. M., Hammond, R. ve Glantz, S., 2008. Tobacco industry attempts to counter the World Bank report Curbing the Epidemic and obstruct the WHO framework convention on tobacco control. Social Science \& Medicine, 67 (11), 1690-1699.

Mukaigawara, M., Winters, J., Fernandes, G. ve Sridhar, D., 2018). Balancing science and political economy: Tobacco control and global health. Wellcome Open Research, 3 (40), $1-16$.

Şahin, H., 2011. Türkiye Ekonomisi: Tarihsel Gelişimi-Bugünkü Durumu. 11. Baskı. Bursa: Ezgi Kitabevi.

T. C. Sağlık Bakanlığı Tütün ve Diğer Bağımlılık Yapıcı Maddelerle Mücadele Daire Başkanlığı, 2014. Küresel Yetişkin Tütün Araştırması Türkiye 2012 [online]. Available from: https://havanikoru.saglik.gov.tr/dosya/dokumanlar/yayinlar/KYTA-2012-TR-2507-2014.pdf [Accessed 24 May 2019].

T. C. Sağlık Bakanlığg Tütün ve Madde Bağımlılığı ile Mücadele Dairesi Başkanlığı, 2019. Türkiyede Tütünle Mücadele Süreci [online]. Available from: https://havanikoru.saglik.gov.tr/surec [Accessed 24 May 2019].

T.C. Tarım ve Orman Bakanlığı Tütün ve Alkol Dairesi Başkanlığı, 2018. Tütün Mamulleri Istatistikleri [online]. Available from: https://www.tarimorman.gov.tr/TADB/Menu/22/Tutun-Ve-Tutun-Mamulleri-Daire-

Baskanligi [Accessed 11 December 2018].

Wipfli, H. ve Samet, J. M., 2016. One Hundred Years in the Making: The Global Tobacco Epidemic. Annual Review of Public Health, 37 (1), 149-166.

Wynder, E. L. ve Graham, E. A., 1950. Tobacco smoking as a possible etiologic factor in bronchogenic carcinoma, a study of six hundred and eighty-four proved cases. The Journal of the American Medical Association, 143 (4), 329-336.

4207 Sayll Kanun, 1996. [online]. Available from: https://www.resmigazete.gov.tr/arsiv/22829.pdf [Accessed 21 May 2019].

4733 Sayılı Kanun, 2002. [online]. Available from: https://www.mevzuat.gov.tr/MevzuatMetin/1.5.4733.pdf [Accessed 22 May 2019].

5727 Sayıl1 Kanun, 2008. [online]. Available from: https://www.resmigazete.gov.tr/eskiler/2008/01/20080119-1.htm [Accessed 22 May 2019]. 
Saraçoğlu S., Öztürk F. (2020), “Türkiye'de Tütün Kontrol Politikaları ve Tütün Tüketimi Üzerine Bir Değerlendirme”, Politik

Ekonomik Kuram, Cilt 4(1)

6354 Sayılı Kanun, 2012. [online]. Available from: https://www.resmigazete.gov.tr/eskiler/2012/07/20120712-12.htm [Accessed 27 May 2019].

7151 Sayll Kanun, 2018. [online]. Available from: https://www.resmigazete.gov.tr/eskiler/2018/12/20181205-8.htm [Accessed 27 May 2019].

27506 Sayılı Resmî Gazete, 2010. [online]. Available from: https://www.resmigazete.gov.tr/eskiler/2010/02/20100227-8.htm [Accessed 26 May 2019].

30701 Sayılı Resmî Gazete, 2019. [online]. Available from: https://www.resmigazete.gov.tr/eskiler/2019/03/20190301-5.htm [Accessed 28 May 2019]. 